\title{
THE CHILDREN OF IMMIGRANTS IN THE SCHOOLS: HISTORICAL ANALOGUES OF EDUCATIONAL DEPRIVATION
}

by

\section{FRANCESCO CORDASCO Montclair State College}

Addresses itself to the experience of the immigrant child in New York City between 1890-1915, affirming that the experience of the immigrant child in other American cities during this period would be the same. In 1906, the N.Y.C. public school enrollment included many foreign-born children (17\%), and the children of immigrants constituted the bulk of the elementary and intermediate school population. More symptomatic than any other factor of the general malaise of the schools was the pervasive phenomenon of the overage pupil who was classified under the rubric "retardation" with all of its negative connotations. The Immigration Commission (1911) found that the percentage of retardation for the N.Y.C. elementary pupils was $36.4 \%$, with the maximum retardation (48.8\%) in the fifth grade. No overall programs were developed to aid any particular immigrant group. The schools were committed to Americanize (and to Anglicize) their charges. Educational theoreticians of the period (e.g., Cubberley) saw the new immigrants as "illiterate, docile, lacking in self-reliance and initiative, and not possessing the Angloteutonic conceptions of law, order, and government . . . " and the school's role was "to assimilate and amalgamate." Parents had virtually no role in the school. Programs were 
designed to suppress or eliminate all that was conceived of as

"foreign" and to impose upon the immigrant child a cultural

uniformity with an American pattern. Bibliographical notes

and extensive documentation.

\section{The Migrations}

Since the keeping of records which were begun in 1819 , it has been estimated that some 43 million human beings made their way into the United States of America, truly one of the greatest peaceful human migrations in the whole history of mankind. Of these, at least 40 million were of European origin and the remainder of widely scattered origins. The bulk of the migration in the period before 1819 (i.e., 1607-1819) came from Northern and Western Europe, and of this a preponderance came from the British Isles; the remainder was from other parts of Europe, and also included an estimated 300,000 blacks mostly brought in as slaves. The period between 1819-1822 is often referred to as the era of the "old migrations" in which some 10 million immigrants arrived, with the majority again originating in Northern and Western Europe. Between 1882-1921 ("the new migration"), the period of the greatest sustained migration, the migrants were largely of Southern and E.astern European origin (some 20 million) out of an estimated 23.5 million. Since 1921, with the imposition of quotas, immigration was drastically reduced, and an effort was made to maintain the basic population composition as it existed in 1890 just prior to the great influx of Southern and Eastern Europeans. Since 1921, and especially after further reductions in 1929, average immigration annually has been about $200,000.1$

The immigrants of the "new migrations" (1822-1921) differed not only in language and customs from earlier American residents, but arrived during those decades when the American "common school" had largely evolved into its framework of "a genuine part of that [American] life, standing as a principal positive commitment of the American people" (Cremin, 1951: 219). The children of the immigrants of this later period presented particular challenges to the American school. With reference to the period between 1880-1920 (particularly, the late 19 th and early 20 th centuries), this paper will present an overview of (1) the American school in form and function as it presented itself to the immigrant child; and (2) the response of the American school to the immigrant child.2

II The American School in Form and Function

The immigrant child was the child of his own immigrant subcommunity within the American city in which his parents had settled. In this immigrant subcommunity (or"ghetto" which carries with it a pejorative connotation), the child was securely related to an organized social life which largely duplicated the customs and mores which his parents had transplanted to America. It was the school which introduced him to a different world, and it was the school which saw its role essentially as one of enforced assimilation. Cubberley, the educational historian, makes this vividly clear:

Everywhere these people [immigrants] tend to settle in groups or settlements and to set up their own national manners, customs and observances. Our task is to break up their groups and settlements, to assimilate or amalgamate these people as a part of the American race, and to implant in their 
chlldren, so far as can be done, the Anglo-Saxon conception of rightlousness [righteousness-sic] 1aw, order, and popular government, and to awaken in them reverance for our democratic institutions and for those things which we as people hold to be of abiding worth (1909: 16; see also Ayres, 1909; and as a point of dissent, Addams, 1908: 99-102).

By $1911,57.5$ percent of the children in the public schools of 37 of the largest American cities were of foreign-born parentage; in the parochial schools of 24 of these 37 cities, the children of forelgn-born parents constituted 63.5 percent of the total registration (U.S. Immigration Commission, "The Children of Immigrants in Schools," Vol. 2, 1911: 1-15). "To the immigrant child the public elementary school was the first step away from his past, a means by which he could learn to assume the characteristics necessary for the long climb upward". (Thomas, 1953-4: 53-67). And by 1911 almost 50 percent of the students in secondary schools were of foreign born parentage. In American cities the major educational challenge and responsibility was the immigrant child.

The situation in New York City was not atypical. Serious deficiences existed in the adequacy of available school facilities. In 1890, it was estimated that in New York City some 10,000 children, who were within the legal ages for school attendance, were without actual school accommodations, and this figure was undoubtedly conservative (N.Y.C. Department of Education, 1898-1915; see also N.Y.C.Commission on Congestion in Population, 1911). The passage of the Compulsary Education Act in 1895, stipulating that all children attend school between the ages of eight and sixteen years (with certain exceptions as to employment, etc.) exacerbated the situation in New York City, and because of the lack of accommodations, the Compulsory Education Act was to all intents inoperative. 3 The expansion of secondary education (three new high schools were opened in 1897) imposed the need for vast curriculum changes in the upper grades of the elementary school, with a concomitant awareness of the need for the expansion of manual training schools. When the Consolidation Act (January 1, 1898) created a greater New York bringing together the boroughs, the schools in the Manhattan and Bronx boroughs were divided into primary and grammar departments with separate classes for boys and girls and elementary schools consisting of seven grades. In the other boroughs the elementary school was organized into eight grades. The first New York City superintendent of Schools, William H. Maxwell, addressed himself to the major problems of the expansion of facilities, the opening of more kindergartens, the uniformity of an eight-year elementary school, and the establishment of manual training schools; and to the problems of urbanization and mounting school enrollments (some 20,000 to 40,000 new students had to be accommodated each year) was added the increasing patterns of heavy immigration. 4

It was against the background of these problems that the immigrant child presented himself to the New York City public schools. By 1900, approximately eighty percent of the New York City population was either foreign-born or of foreign-parentage, and by 1910 a significant shift in the birthplace of the majority of the immigrants from the north to the south of Europe had occurred. For the schools, the non-English speaking child presented still another dimension to overwhelming problems.5 The Third Biennial School Census in 1906 showed that 17 percent of the entire public school enrollment was foreign-born (113, 740), and although there was some controversy about the accuracy of the figures (particularly, that the figures did not reflect cases of truancy and the number of children working illegally), the enormity of the problems presented to the schools was dramatically underscored (N.Y.C. Department of Education, 1906-7; also Haney, 1910). The children of the more recent immigrants constituted the bulk of 
elementary and intermediate enroflments, while the children of earlier immigrants were generally in higher grades. More symptomatic than any other factor of the general malaise of the schools was the pervasive phenomenon of the overage pupil who was classed under the rubric "retardat1on" with all of its negative connotations. The Immigration Commission of 1911 found that the percentage of retardation for the New York City elementary school pupils was 36.4 , with the maximum retardation ( 48.8 percent) in the fifth grade (Vo1. 32, p. 309). The Commission observed:

...thus in the third grade the pupils range in age from 5 to 18 years. In similar manner pupils of the age of 14 years are found in every grade from the first of the elementary schools to the last of the high schools. It will, however, be noted that in spite of this divergence the great body of the pupils of a given grade are of certain definite ages, the older and younger pupils being in each case much less numerically represented. It may, therefore, be assumed that there is an appropriate age for each grade. This assumption is the cardinal point in current educational discussion in regard to retardation. If it were assumed that there is a normal age for each grade, then the pupils can be divided into two classes--those who are of normal age or less and those who are above the normal age. The latter, or overage pupils, are designated as 'retarded 17 (Vol. 32, p. 608-9).

Although the Immigration Commission concluded that the "races" which had most recently arrived in the United States (and in which a foreign language was used in the home) had a higher percentage of retardation, it cautioned against deriving from these data less mental ability, but rather ascribed the retardation to environmental and external circumstances that would be corrected within a generation.

That the educational system was inadequate to the problems presented is unquestioned. In the main, there was a slow shift from concern with the problems of physical facilities, of congestion, to the more important concern of the needs of immigrant children with the problems of their maladjustment, "retardation," with the particular needs of ethnic groups, with the preservation of the multicultures which the children brought to the schools, and to the articulation of a learning situation which was fashioned out of new curricula and understandings (Cremin, 1961: 66-75; and particularly Cove11o, 1936).

III The Response of the American School to the Immigrant Child

In the effort to respond to the immigrant child, it is important to note at the outset that no overall programs were developed to aid any particular immigrant group. Although there was little agreement as to what Americanization was, the schools were committed to Americanize (and to Anglicize) their charges. Ellwood P. Cubberley's Changing Conceptions of Education, which Lawrence A. Cremin characterizes as "a typical progressive tract of the era," (1961: 68)8 saw the new immigrants as "illiterate, docile, lacking in self-reliance and initiative, and not possessing the Anglo-teutonic conceptions of $1 \mathrm{aw}$, order, and government ...," and the school's role was (in Cubberley's view) "to assimilate and amalgamate."

What efforts were made to respond to the needs of immigrant children were improvised, most often directly in answer to specific problems; almost never was 
any attempt made to give the school and its program a community-orientation. The children 1iterally left at the door of the school their language, their cultural identities, and their immigrant subcommunity origins.9 The child's parents had virtually no role in the school;10 and the New York City experience was not atypical in its leaving the immigrant child to the discretion of the individual superintendent, a principal, or a teacher. In New York City no citywide system or policy was developed to meet the special needs presented by the immigrant child. Instead, largely left to the management of district superintendents, constructs and programs evolved along the broad lines of individual promotion; English instruction for forelgners; the provision of special classes; and, in some instances, of special schools.'

Julia Richman, district superintendent in New York City School Districts 非 2 and 非3, was particularly responsive to the needs of immigrant children. She experimented with a new system of individual promotion (in essence, graded patterns of instruction geared to individual needs), and her writings show a growing awareness of the need for community liaison and support.11 As early as 1903, other district superintendents in Division I, embracing Manhattan south of 14 th Street, were experimenting with a syllabus of instruction for teaching English to children who did not know the language (Wade, 1903: 285-92). Certain superintendents instituted special classes for immigrant children (extending from one month to a whole year) for basic instruction in English which would bring them to grade level. 12 And the most ambitious of the constructs devised was the largescale introduction of special classes by Julia Richman throughout the school districts under her governance. These efforts by Julia Richman are worthy of special note.

On 1903, Julia Richman conducted an investigation in her school districts to determine why so many children who applied to leave school were not at the fifth grade level (legally, children could leave school by age 14); and she maintained that the clearest indication of the failure of the schools was in the fact that large numbers of children desiring to leave school for employment at age 14 , were not at fifth grade level. Students who were fourteen and had completed Grade 5A or its equivalent were eligible for work certification. Miss Richman found that pupils who were not progressing could be classified as follows:

(1) Foreign-born children longer than one year in the city were unwisely classified and too slowly promoted.

(2) Children who were turned away from school or kept for years on waiting lists in the days when principals had that privilege.

(3) Children "run out of school" for misconduct when records were kept less carefully than at present.

(4) Children excluded because of contagion in the days when medical personnel and nurses were not able to control this situation.

(5) Children who had been neglected in classes where substitutes were placed in charge of afternoon part-time classes.

(6) Disorderly children.

(7) Truants.

(8) Defectives (mental or physical).

(9) Children whose individual needs were overlooked when promotions were made (1904: 129-30).

On the basis of these findings, Julia Richman received permission from the Board of Superintendents to allow her to form special classes for these children in which 
a simplified and individualized course of study was to be used. Only the absolute essentials demanded by the compulsory attendance law were to be taught.

The omission of paper folding, construction of paper boxes, the knotting of cord, sight reading in music, illustrative dawing and many other requirements of our present course (even though they have a distinct educational value to the normal child of English speaking parents) will make it possible to cover the work of two or more grades in one term. This will bring these children nearer to the completion of the requirements of the law by their 14th birthday (1904: 130).

By September 30,1904 , some 18 special classes had been instituted in School Districts 2 and 3 ; and a significant reversal was made in the earlier practice of placing the immigrant child, whatever his age, in the lowest or next lowest grade. And by the end of the 1904-05 school year, some 250 special classes (principally for non-English speaking children) were in operation (N.Y.C. Department of Education, 1904-5). As children acquired a competency in English, they were transferred to appropriate grades. Generally, an overall improvement was noted with continuing difficulties only with those students who were highly transient and for whom the continuity of instruction was interrupted. Yet, even these difficulties were minimized by special efforts and adaptations (N.Y.C. Department of Education, 1904-5: Appendix A, 137).13 Further refinements of the special class concept led to the definition of three categories of placement: Grade C for foreign-born children who did not speak English; Grade D for those pupils who were approaching age 14, could not finish elementary school, and wished to obtain work certificates; and Grade E for those pupils who hoped to graduate but needed special help to enter the 7 th grade (N.Y.C. Department of Education, 1905-6). There is little doubt that the special classes were an effective force in meeting the needs of the immigrant child; and an inconsiderable number of native-born children received needed help as well. 14

Although the special classes gave principals and teachers considerable latitude in dealing with the problems of immigrant children, no effort was made to change the basic course of study in the regular classes to which these children eventually moved. Out of mounting criticism that the New York City school curriculum was inflexible, and not geared to the wide variety of needs exhibited by children, came recommendations for industrial education, for vast curricular reforms (largely unmet) and the creation of schools for incorrigible boys:

(Russel1, 1911: 141-3; Haus, 1913; and for "incorrigible" child, Richman, 1906: 484-506) the forerunner of the present day "600" schools. The emphasis on industrial education was a continuing reiteration of the need for manual education; a private manual training school had been established in New York City in 1887, and the city's Baron de Hirsch School (1891) trained boys for the mechanical and building trades (Cremin, 1961: 24-57). And the emphasis on manual and trade education (no matter how inadequately met) may have been the surest symptom of a school system which found the children of immigrants uneducable along traditional lines. 15

That the public schools in New York City were unable, or unwilling to meet the challenge of immigrant children is readily apparent in the paucity of the concepts and programs which were fashioned; in a few educational reformers (e.g., Julia Richman) who responded constructively to the multitude of challenges; and particularly in the continuing criticism of the schools by a host of lay reformers; and in the variety of non-school agencies which were created to meet the very 
real problems which the schools ignored. Most of the soclal reformers directed their criticisms to the schools, and of these Jacob A. Rils, Robert Hunter, and John Spargo are but a few whose writings are valuable chronicles of the deficiencles of the schools (Riis, 1892; Hunter, particularly chapter entitled, "The Ch1ld," 1904; Spargo, 1907; and Cordasco, 1968c); and despite 1ts 1ntricate Involvements, The Public Education Association of New York City formulated a conception of the public school as "a legatee institution" whose responsibility (as the PEA saw it) was the entire problem of child life (Cohen, 1964). And central in the community mosaic of the urban Settlement House was provision for all those identities which poor youth sought and were denied in the schools.16

The schools reflected the attitudes prevalent at the time of the great 1mmigrationswhich, in essence, held that the immigrant was a one-generation problem. Assimllation was an educational process, and if immigrant children got a "good" education, the parents would be assimilated with them. In the process, parents and community were neglected, if not ignored. There is some doubt that the school acted as the main devise through which the child was assimilated, and if 80 , it did its job poorly; certainly, the schools did not ameliorate the plight of the immigrant parent: if anything they provided little opportunity to the immigrant parent to obtain information as to what the aims and objectives of the schools were, and in this respect the schools and the parent were in continuing conflict. If New York City was typical, the urban schools provided no system-wide policy which dealt with the educational needs of immigrant children; and where programs were fashioned to meet these needs, there was no attempt made to differentiate between immigrant groups (e.g., the experlence of Italian and Jewish children in New York City strongly documents this failure): instead children were lumped under the rubrics "native-born," or "foreign-born." If one discounts the multipliclty of disfunctional programs, rampant discrimination, authoritorian prejudice, it is still difficult to attribute the general patterns of fallure to immigrant children or their parents. The blame for the failure lies almost wholly within the school and the dominant society which shaped its programs and articulated tts cultural ideals.

Leonard Covelio, who spent a half century in the New York City schools as a teacher and an administrator, himself an immigrant child in its schools, observed, "Of no importance was the fact that the Americanization programs were directed only toward people of foreign stock, without giving any consideration to the necessity of involving all Americans, regardless of the time of their arrival in the United States. But, above all, the earlier Americanization policies, by and large, denied or neglected the strength of, and the values in, the foreign culture of immigrant groups. The concept of Americanization was based upon the assumption that foreigners and foreign ideas and ways were a threat to American political, economic, social stability, and security. The infiltration of foreign culture,it was feared would eventually bring about a deterioration of the American 'way of life! Programs were designed, therefore, to suppress or eliminate all that was conceived of as 'foreign' and to impose upon the immigrant a cultural uniformity with an American pattern (1967: 411). 
${ }^{1}$ A vast literature exists on immigration. See Haskett (1956: 85-295). Particular reference should be made to Jenks and Lauck (1917) and U. S. Immigration Commission (1911: 41 vols.).

2 The paper limits itself to the experience in New York City, and largely to the period between 1890 and 1915. It is the writer's view that the experiences of the immigrant child in other American cities during this period would be essentially the same, and if different that differences would be in terms of the size of the immigrant subcommunity, its spatial distribution within the greater urban context, and in differences in responses by the schools.

3 The biennial school census in 1895 showed that there were 166,000 nonattendant children in the city who were entitled to enter school. See New York City Board of Education, 1896: 4-5.

${ }^{4}$ For the population growth in New York City between 1890-1910, see U.S. Census Bureau (1910: 569-71); and for growth in school population, see N.Y.C. Department of Education (1899, et. seq.).

${ }^{5}$ See H.H. Wheaton (1915) in which it is noted that in 1910 there were in New York City 421,951 persons ten years of age or over who could not speak English, and over 245,000 in the same category who were illiterate.

${ }^{6}$ See generally the United States Immigration Commission (1911: vols. 29-33); for New York City, see vo1. 32, pp. 603-765. "On the other hand, there are several races which have an unusually high portion of their children in the schools. These are the Greeks, the North and South Italians, the Poles, and Roumanians, the Spaniards, and the Syrians. This may be due to the recent immigration of these races and the preponderance among their children of those of early ages, as well as to the fact that where the children are themselves born abroad and are ignorant of the English language they are frequently forced to begin their work in the public schools of the United States at a point considerably below that which corresponds to their age." (U.S. Immigration Commission, 1911: 613); in its conclusions, the Immigration Commission noted of the pupils who are children of foreign-born fathers, three races--the Portuguese, Slovak, and South Italian-show less than one percent in the high school." (U.S. Immigration Commission, 1911: vol. 1, p. 43).

7 The Commission further noted: "Again certain races may be noted which have a less proportion of retarded children than has the group of native parentage. They are the Danish, the Finnish, the German Hebrew, the Roumanian Hebrew, the Magyar, the Norwegian, the Roumanian, the Russian, and the Swedish. It cannot fail to attract attention that many of these races are those of comparatively recent immigration. On the other hand, there are some races with a conspicuously high degree of retardation among the children. These are the French Canadian, the Greek, the Italian, the Spanish, the Spanish-American, and the Syrian " (vol. 32 , p. 614). General reference should be made to Leonard P. Ayres (1909) which, in an effort to determine the causes of retardation, conducted studies in twentynine cities and which includes a detailed study of 20,000 children in fifteen Manhattan schools. Ayres concluded that slow progress (note late entrance) was the greatest factor in retardation. 
8"To Americanize, in this view, was to divest the immigrant of his ethnic character and to inculcate the dominant Anglo-Saxon morality" (Cremin, 1961: 68). See also Frank V. Thompson, (1920) for a more eclectic view; and for the more pragmatic efforts of the Settlement Houses and other non-school agencies, see Robert A. Woods, et. al., (1895); and Morris I. Berger, (1956).

${ }^{9}$ See the autobiography of Leonard Covello, (1958). It is significant to note that Covello, as an immigrant boy in East Harlem, was more influenced by the work of the evangelist Anna C. Ruddy, who had devoted years to social work in the East Harlem Italian Community, than by the public schools. See Anna C. Ruddy [pseudonym, Christian McLeod], (1908); see also Selma Berrol (1969: 220-30).

${ }^{10}$ See Leonard Covello with an Introduction by F. Cordasco (1967). As late as 1938, Phyllis H. Williams, in a study under the aegis of the Institute of Human Relations, Yale University, observed: "Current theories of child training in American schools stress the pupil's role as an individual rather than as a group member. Teachers frequently expect the American-born child of Italian stock to manifest purely American traits, to have sloughed off almost all of the culturally determined personality traits that characterize his parents. When they attribute any variation to ethnic differences, they usually do so in the case of a vice rather than a virtue--in.a typically ethnocentric fashion." (1938; reissued with an Introductory Note by $F$ : Cordasco, 1969: 132). The persistence of an ethnocentric rejection of the use of native languages in the instruction of non-English speaking children can be studied in the recent history (196667) of the enactment of Title VII (Bilingual Education Act) of the Elementary and Secondary Education Act. See F. Cordasco,"The Bilingual Education Act," (1969); and F. Cordasco, "The Challenge of the Non-English Speaking Child in American Schools," (1968a), which is an adaptation of testimony before the Committee on Education and Labour of the U. S. House of Representatives in support of the proposed Title VII (June 29, 1967). See further Mario Fantini and Gerald Weinstein (1968); and a critique-review by F. Cordasco, "Educational Pelagianism: The Schools and the Poor," (1968b).

${ }^{11}$ All of Julia Richman's writings are important. See particularly: 1899; 1906 ; 1910 ; and 1904 .

12 Basically, this technique was extensively used in meeting the English language needs of Puerto Rican children following the heavy migrations to American cities after World War II. See F. Cordasco and E. Bucchioni (1968d).

13 Since the special classes were largely for non-English speaking immigrant children, lay observers of the public schools continued to call for restriction of immigration as a solution to school problems. Cf., Adele Marie Shaw, 1903. More sympathic to public school efforts (and often the catalyst which brought them into being) was The Public Education Association of New York City which had been formed in 1894. See the invaluable study by Sol Cohen, 1964.

${ }^{14}$ See the results of an investigation of special classes which was conducted in 1909-1910. New York City Department of Education, 1911-1912. See also, Bureau of Education, 1913.

15 S. Cohen (1968: 95-110) has cogently advanced the thesis that the industrial education movement was an attempt to block the social advance of immigrant 
${ }^{16}$ On the Settlement House movement, see M. I. Berger, 1956; and Robert A. Woods and Albert J. Kennedy, 1922. On the educational and social aspirations of ethnic subcommunities, see Timothy L. Smith, 1969: 523-43. 


\section{References}

Add ams, Jane

1908 "The Public School and the Immigrant Child." National Education Association Journal. 46: 99-102.

Ayers, Leonard P.

1909 Laggards in Our Schools. New York: Russell Sage Foundation.

Berger, Morris I.

1956 "The Settlement, the Imnigrant and the Public School" (unpublished Ph.D. dissertation, Columbia University).

Berrol, Selma

1969 "Immigrants at School: New York City, 1900-1910." Urban Education. 4 (October): $220-30$.

Cohen, Sol

1964 The Public Education Association of New York City, 1895-1954. New York: Bureau of Publications, Teachers College, Columbia University.

Cohen, S.

1968 "The Industrial Education Movement, 1906-1917." American Quarterly. 20 (Spring): 95-110.

Cordasco, Francesco

1968a "The Challenge of the Non-English Speaking Child in American Schools." School \& Society. 96 (march 30): 198-201.

1968b "Educational Pelaglanism: The Schools and the Poor." Teachers College Record. 69 (April): 705-9.

1968c Jacob Ril's Revisited: Poverty and the Slum in Another Era. (Ed.). New York: Doubleday,

1968d and E. Bucchioni. Puerto Rican Children in Mainland Schools: A Sourcebook for. Teacher. New York: Scarecrow Press.

1969 "The Bilingual Education Act." Phi Delta Kappan. 51 (October): 75.

Cove110, Leonard

1936 "An High School and Its Immigrant Community: A Challenge and an Opportunity." Journal of Educational Soclology. 9 (February): 331-46.

1958 The Heart is the Teacher. New York; McGraw-H111.

1967 The Social Background of the Italio-American ChildiA Study of the Southern Italian Family Mores and Their Effect on the School Situation in Italy and America. Leiden, The Netherlands: E. J. Brill.

Cremin, Lawrence A.

1951 The American Common School: An Historic Conception. New York: Bureau of Publication, Teachers College, Columbia University.

1961 The Transformation of the School. New York: Knopf.

Cubberley, Elwood P.

1909 Changing Conceptions of Education. Boston: Houghton Mifflin.

Fantini, Mario and Gerald Weinstein

1968 The Disadvantaged: Challenge to Education. New York: Harper.

Haney, John D.

1910 Registration of City School Children. New York: Teachers College, Columbia University. 
Hanus, Paul

1913 School Efficiency: A Constructive Study Applied to New York City. New York: World Book.

Haskett, Richard C., et. al.

1956 "An Introductory Bibliography for the History of American Immigration." In A Report on World Population lifigrations, Washington: The George Washington University Press.

Hunter, Robert

1904 Poverty. New York: Macmillan.

Jenks, Je remiah W. and W. Jett Lauck

1917 The Immigration Problem. New York: Funk and Wagnalls.

New York City Board of Education

1896 "Report of Finance Committee on School Systems."

New York City Commission on Congestion of Population

1911 Report of the Committee

New York City Department of Education

1898- Annual Reports of the City Superintendent of Schools to the Board of Educa1915 tion.

Richman, Julia

1899 "As Successful Experiment in Promothing Pupils." Educational Review. 181 (June): 23-29.

1906 "The Incorrigible Child." Educational Review. 31 (May): 484-506.

1910 "The Social Needs of the Public School." Forum. 43 (February): 161-9.

1904 "What Can Be Done in the Graded School for the Backward Child." The Survey. 13 (November): 129-31.

Riis, Jacob A.

1892 The Children of the Poor. New York: Scribner's.

Ruddy, Anna C.

1908 The Heart of the Stranger. New York: Fleming H. Rovell.

Russe11, Isaac

1911 "Is Our Public School Behing the Times? James Creelman's Remedy for Existting Evils." The Craftsman. 20 (May): 141-3.

Shaw, Marie

1903 "The True Character of New York Public Schools." World's Work. 7 (December): 4204-21.

Smith, Timothy L.

1969 "Immigrant Social Aspirations and American Education, 1880-1930." American Quarterly. 21 (Fal1): 523-43.

Spargo, John

1907 The Bitter Cry of the Children. New York: Macmillan.

Thomas, Alan $M$.

1953- "American Education and the Immigrant." Teachers College Record. 55: 253195467.

Thomps on, Frank V.

1920 Schooling of the Immigrant. New York: Harper.

United States Bureau of Education

1913 Bulletin. No. 51. 
Unt ted States Census Bureau

1910 Thirteenth Census of the United States, Supplement for New York City. United States Immigration Commission

1911 Reports. 41 vols. Washington: Government Printing office.

Wade, Joseph S.

1903 "The Teaching of English to Foreigners in the First Two Years of Elementary School." School Work 2(November): 285-92.

Wheaton, H.H.

1915 Recent Progress in the Education of Immigrants. Washington: Government Printing office.

Williams, Phyllis H.

1938 South Italian Folkways in Europe and America: A Handbook for Social Workers, Visiting Nurses, School Teachers, and Physicians. New Haven: Yale University Press.

reissued in

1969 (same title) New York: Russell \& Russell.

Woods, Robert A., et. al.

1895 The Poor in Great Cities: Their Problems and What Is Being Done to Solve Them. New York: Scribner's.

Woods, Robert A. and Albert J. Kennedy

1922 The Settlement Horizon. New York: Macmillan. 